\title{
Testisin Seks Kord/Stromal Tümörlerinde Güncel Tedavi Yaklaşımları
}

\section{Current Treatment of Testicular Sex Cord-Stromal Tumors}

\author{
Dr. Şahin Kabay1, Dr. Mithat Ekici2 \\ ${ }^{1}$ Dumlupınar Üniversitesi Tıp Fakültesi, Üroloji Anabilim Dalı, Kütahya, Türkiye \\ 2Dumlupınar Üniversitesi Tıp Fakültesi, Evliya Çelebi Eğitim ve Araştırma Hastanesi, Üroloji Kliniği, Kütahya, Türkiye
}

\section{Özet}

Testisin seks kord/stromal tümörleri nadir olarak görülürler. Seks kord/ stromal tümörlerin az bir kısmı maligndir ve ilk tanı anında metastatik olarak tespit edilir. Standart tedavileri inguinal orşiektomi olmasına rağmen testis koruyucu cerrahi frozen inceleme sonucunda benign karakterdeki kitlelere önerilmektedir. Bu derlemenin amacı seks kord/ stromal tümörlerinin günümüzde kabul edilen standart ve alternatif tedavi alternatiflerini değerlendirmektir. (Üroonkoloji Bülteni 2014;13:153-156)

Anahtar Kelimeler: Testis Tümörü, testisin seks kord/stromal tümörü, leydig hücreli tümör, sertoli hücreli tümör, testis koruyucu cerrahi

\begin{abstract}
Summary
Sex cord-stromal tumors are rare testicular tumors. A few of sex cordstromal tumors are malignant and may be detected as metastatic at initial diagnosis. Although the standard treatment is inguinal orchiectomy, testis sparing surgery is recommended for masses that have benign characteristics on frozen section analysis. The aim of this review was to evaluate the currently accepted standart and alternatives treatment modalities for sex cord-stromal tumors. (Bulletin of Urooncology 2014;13:153-156)
\end{abstract}

Key Words: Testicular tumor, testicular sex cord-stromal tumors, leydig cell tumors, sertoli cell tumor, testis sparing surgery

\section{Giriş}

Testis tümörü erkek kanserleri arasında \%1-\%1,5 oranında görülürken tüm ürolojik tümörlerin \%5'ini oluşturmaktadır. Özellikle genç yaş grubu erkeklerde en sık görülen malign tümörlerdendir (1). Testisin seks kord/stromal tümörleri (TSST) nadir olarak görülür ve yetişkin testis tümörlerinin sadece \%2-\%4'ünü oluştururlar. Leydig hücreli tümörler TSST'nin \%75$\% 80$ 'ini oluştururken sertoli hücreli tümörlerden üç kat daha fazla görülürler (2). Bugüne kadar Avrupa Üroloji Derneği dışında TSST için herhangi bir genel öneri yayınlanmamıştır. Avrupa Üroloji Derneği Testis Kanseri Çalışma Grubu bu konu ile ilgili klavuz hazırlamış ve sadece Leydig ve Sertoli hücreli tümörlerin tanı ve tedavisi için öneriler vermiştir (3). Non-germ hücreli testis tümörleri TSST ve çeşitli non-spesifik stromal tümörleri içermektedir ve farklı histolojik alt tipleri Dünya Sağlık Örgütü (WHO) 2004 sınıflamasına göre tanımlanmıştır (4) (Tablo 1). TSST'leri ilk tanı anında \%20 metastatik olarak tespit edilirler ve takiplerde ilk iki yıl içerisinde hastaların \%40'ında metastaz gelişir. En sık metastazlar özellikle retroperitoneal ve inguinal lenf nodlarına (\%70), karaciğer (\%45), akciğer (\%40) ve kemikleredir (\%25) (5). Jinekomasti germ hücreli tümörlerde insan koryonik gonodotropin, insan koryonik somatomammotropin, prolaktin, östrojen, androjenlerin artmış seviyelerine bağlı olarak hastaların \%5'inde görülürken, TSST'li hastaların \%10-\%30'unda görülür. jinekomasti genellikle orşiektomiden sonra bir yıl içinde \%80 oranında gerileme gösterir. Jinekomastisi devam eden hastalarda bilateral mastektomi önerilebilir. Bazı araştırmacılar devam eden jinekomastinin tanı konulamamış bilateral leydig hücreli tümörlerde (\%3), metastatik hastalık ve rekürrenslerde görülebileceğini bu nedenle orşiektomi sonrası takiplerde jinekomasti için fizik muayenenin yapılması önerilmektedir $(2,3,4,5)$.

$\mathrm{Bu}$ derlemede TSST'lerin güncel veriler eşliğinde günümüzde kabul edilen standart ve alternatif tedavilerinin değerlendirilmesi amaçlanmıştır.

\section{Leydig Hücreli Tümörler}

TSST içinde en sık görülen tümörlerdir. Leydig hücreli tümörler erişkin testis tümörlerinin yaklaşık \%1-\%3'ünü oluştururken 


\begin{tabular}{|l|l|}
\hline $\begin{array}{l}\text { Tablo 1. Dünya Sağlık Örgütü (WHO) } 2004 \text { sınıflamasına göre } \\
\text { non-germ hücreli tümörler }\end{array}$ \\
\hline \multicolumn{2}{|l|}{ Seks Kord/Gonadal Stromal Tümörler } \\
\hline Leydig hücreli tümör & \\
\hline Malign Leydig hücreli tümör & \\
\hline Sertoli hücreli tümör & Lipitten zengin varyant \\
\hline & Sklerozan \\
\hline & Büyük hücreli kalsifiye \\
\hline & \\
\hline Malign Sertoli hücreli tümör & \\
\hline Granuloza hücreli tümör & Erişkin tip \\
\hline & Genç tip \\
\hline & \\
\hline Tekoma/fibroma grubu tümörler & \\
\hline $\begin{array}{l}\text { Diğer seks kord/gonadal } \\
\text { stromal tümörler }\end{array}$ & Inkomplet diferansiye \\
\hline & Miks \\
\hline $\begin{array}{l}\text { Non-spesifik stroma tümörleri } \\
\text { (benign ve malign) } \\
\text { tümör içeren tümörler } \\
\text { (gonodoblastoma) }\end{array}$ & \\
\hline Çeşitli nonspesifik stromal tümörler & \\
\hline Ovaryen epitelyal tümörler & \\
\hline Toplayıcı kanal ve rete testis tümörleri & \\
\hline & \\
\hline
\end{tabular}

çocuk ve infantlarda \%3'ünü oluşturmaktadır. Bu tümörler en sık olarak erişkinlerde 30-60'lı yaşlarda görülürken çocuklarda 3-9 yaşları arasında görülmektedir. Leydig hücreli tümörlerin sadece \%3'ü bilateral olarak tespit edilirler. Bazen Klinefelter sendromlu hastalarda da oluşurlar $(5,6)$. Bu tümörlerin yaklaşık $\% 10$ 'u maligndir. Büyük boyut $(>5 \mathrm{~cm})$, sitolojik atipi, DNA anöploidisi. mitotik aktivite artışı (her 10'luk büyütme alanı için >3) MIB-1 ekspresyon artışı, nekroz vasküler invazyon, infiltratif marjinler, testis parankimi dışına yayılma malignite kriterleri olarak değerlendirilir $(3,7,8)$. Histopatolojik olarak düzgün sınırlı ve genellikle büyüklüğü en fazla $5 \mathrm{~cm}$ çapındadır. Sarımsı kahverengi ile sarı renkte görülürken olguların \%30'da kanama ve/veya nekroz alanları mevcuttur. Mikroskobik olarak hücreleri poligonal ara sıra Reinke kristalleri içeren eozinofilik sitoplazmalı düzgün nukleuslu solid yapıdadır ve kapiller stroma içerirler. Hücreler vimentin, inhibin, S-100 protein, steroid hormonlar, kalretinin ve sitokeratin eksprese ederler (4). Tümör testiste ağrısız büyüme ya da insidental ultrasonografi bulgusu olarak saptanır ve hastaların \%80'e varan oranında bu bulguya yüksek östrojen, östrodiol ve düşük testestoron seviyeleri ile birlikte artmış LH, FSH seviyelerini eşlik ettiği hormonal değişiklikler eşlik eder. AFP, hCG, LDH ve PLAP gibi serum tümör belirteçleri negatiftir ve yaklaşık hastaların \%30'unda jinekomasti görülür $(9,10)$. Leydig hücreli tümörler multinodüler tümör ve sıklıkla bilateral oluşan androgenital sendrom lezyonlarından ayrılmalıdır (11). Küçük asemptomatik tümörler sıklıkla germ hücreli tümörler gibi yorumlanarak inguinal orşiektomi yapılır. Son yıllarda nonpalpapl $2 \mathrm{~cm}$ 'den küçük intraparankimal lezyonlar için histolojik tanı elde etmek için organ koruyucu cerrahini yapılması tavsiye edilmektedir. Özellikle jinekomastili ve/veya hormonal bozukluğu olan hastalar non-germ hücreli tümörler olarak düşünülmeli ve inguinal parsiyel orşiektomi yapılmalı, parsiyel orşiektomi sonrası malign histolojik bulgu tespit edilen stromal tümörlerde ve özellikle yaşlı hastalarda metastazı önlemek için inguinal orşiektomi ve retroperitoneal lenfadenektomi yapılmalıdır. Histolojik olarak malign bulguları olmayan hastalarda orşiektomi sonrası bireyselleştirilmiş takip stratejisi izlenmelidir. Spesifik tümör belirteçleri olmadığından CT ile takip en uygun yöntemdir. Lenf nodları, akciğer, karaciğer, kemik gibi metastazlarında kemoterapi ve radyoterapiye iyi yanıt vermezler ve yaşam süreleri kötüdür $(12,13,14)$.

\section{Sertoli Hücreli Tümörler}

Sertoli hücreli tümörler testis tümörlerinin \%1'inden daha azını oluştururlar ve tanı anındaki yaklaşık ortalama yaş $45^{\prime}$ tir ve 20 yaşın altında nadir olarak görülürler (15). Nadir durumlarda bu tümörler androjen insensitivite sendromu ve Peutz-Jeghers sendromlu hastalarda gelişebilir. Malign tümör görülme oranları \%10-\%22 arasındadır ve şimdiye kadar 50'den daha az olgu bildirilmiştir (16). Malignite bulguları büyük boyut $(>5 \mathrm{~cm})$, çekirdekçik içeren pleomormik çekirdekler, mitotik aktivitede artış (her 10'luk büyütme alanı için >5), nekroz, vasküler invazyondur $(15,17)$. Bu tümör iyi sınırlı, sarı, bronz ve beyaz renktedir ve ortalama çapları 3,5 cm'dir. Mikroskopik incelemede hücreler eozinofilikten soluğa giden vakualize sitoplazmalıdır, çekirdekleri düzenlidir ve inklüzyon cisimcikleri de içerebilirler. Hücreler solid veya tübüler düzenlenmiştir. Hücreler vimentin, sitokeratin, inhibin (\%40) ve protein S-100 (\%30) eksprese ederler. Tümör testiste büyüme ya da insidental ultrasonografi bulgusu olarak saptanır. Çoğu klasik sertoli hücreli tümörler tek taraflı ve tek odaklıdır. Jinekomasti bazen görülmesine rağmen hormonal bozukluklar nadiren görülür (18). Testiküler tümör belirteçleri her zaman negatiftir. Ultrasonografik olarak genellikle hipoekoiktirler ve büyük hücreli kalsifiye formlardaki alt tipi dışında germ hücreli tümörlerden ayırt edilemezler. Büyük hücreli kalsifiye formları genellikle gençlerde görülür ve genellikle genetik sendromlar (Carney Kompleksi, Peutz-Jeghers sendromu) veya olguların yaklaşık $\% 40$ oluşturan endokrin hastalıklarla ilişkilidir. Bu olguların $\% 44$ 'ü senkron ya da metakron olarak bilateraldir \%28'i ise multifokaldir $(19,20,21)$. Histopatolojik olarak yukarıda tanımlanan bulgular çerçevesinde malign rapor edilen hastaların (ortalama \%18,8) takipleri sırasında ancak \%7'sinde metastatik hastalık bildirilmiştir (3). Uzun süreli takip ve büyük bir serinin yayınlandığı çalışmada hastaların \%7,5'u malign olarak bildirilmiş uzun süreli takiplerde ise $\% 11,7$ metastatik hastalık görülmüştür (18). Büyük hücreli sklerozan formların \%20'ne yakını maligndir. Metastatik hastalık sklerozan alt tipinde nadir olarak görülür. Sertoli hücreli tümörler sıklıkla germ hücreli tümörler olarak yorumlanırlar ve inguinal orşiektomi yapılır. Bu tümörlerde kesin histopatolojik sonuç alınana kadar özellikle küçük intraparankimal tümörlerde, jinekomastili hastalarda, hormonal bozukluğu olan hastalarda ultrasonografik olarak tipik kalsifikasyonlar görüldüğünde organ koruyucu cerrahi uygulanması önerilmektedir. Maligniteye ait bulgular mevcutsa özellikle yaşlı hastalarda orşiektomi yapılmalıdır. Histolojik 
olarak malign bulguları olmayan hastalarda orşiektomi sonrası bireyselleştirilmiş takip stratejisi izlenmelidir. Spesifik tümör belirteçleri olmadığından CT ile takip en uygun yöntemdir. Lenf nodları, akciğer, karaciğer, kemik gibi metastazlarında kemoterapi ve radyoterapiye iyi yanıt vermezler ve yaşam süreleri kötüdür (3).

\section{Granuloza Hücreli Tümörler}

Genç ve erişkin olarak iki alt tipi bulunan nadir tümörlerdendir. Genç alt tipi benigndir. Konjenital testiküler tümörlerin en sık görülenidir ve puberte öncesi tüm testiküler kitlelerin $\% 6,6$ oluştururlar. Kistik görünümleri bu tümörlerin karakteristik özellikleridir (22). Erişkin tipin ortalama görülme yaşı $44^{\prime}$ dür. Homojen, sarı gri renkli, mikrofoliküler uzamış hücreler ve Call-Exner cisimcikleri gibi tipik morfolojik özellikleri vardır. Malign tümörler olguların yaklaşı \% 20 'sinde görülür ve çapları genellikle $7 \mathrm{~cm}$ 'nin üzerindedir. Vasküler invazyon ve nekrozis malign biyolojik özellikleri gösterir (23).

Diğer alt histolojik gruptaki tümörler çok nadir görülürler ve tedavi açısından standart öneriler sunmak içi yeterli literatür bilgisi mevcut değildir $(3,4,24)$.

Güncel Tedavi Yaklaşımı Açısından Testis Koruyucu Cerrahi Testis tümörleri ile ilgili alternatif tedavi yöntemlerinden biri de testis koruyucu cerrahidir $(25,26)$. Bilindiği gibi günümüzde malign ve orijini bilinmeyen testis tümörlerinin tedavisi radikal orşiektomidir. Zaman içerisinde testis tümörü ön tanısıyla radikal orşiektomi yapılan olguların \%31'inde histopatolojik olarak ispatlanmış benign testis tümörlerinin yüksek oranının belirgin hale gelmesi ve frozen kesitlerden yüksek tanısal doğruluk elde edilmesi hemen radikal orşiektomiye intiyaç kalmayabileceğini göstermiştir. Ayrıca ultrasonografinin yaygın kullanılması insidental küçük benign kitlelerin saptanmasını belirgin olarak arttırmıştır. Yalnızca bilateral testis tümörü ya da monorşik testiste değil, diğer testisin sağlam olduğu durumlarda da testis koruyucu cerrahi söz konusu olabilmektedir $(27,28)$. Bu amaçla yapılmış çalışmalara bakıldığında Passarella ve ark. tarafından benign tümör ön tanısıyla testiste kitlesi bulunan hastalara testislerini korumak amaciyla inguinal eksplorasyon ve şüpheli alanlardan eksizyonel biyopsi ile frozen incelemesi yapılmıştır. Frozen sonucu benign olarak değerlendirilen hastalara testis koruyucu cerrahi yapılırken, malign olarak belirtilen 2 hastaya orşiektomi yapılmışır. Postoperatif yapılan histopatolojik değerlendirme sonucunda tüm hastaların frozen ile uyumlu olduğu saptanmıştır. Sadece frozen ile 2 hastada benign-malign ayııımı yapılamadığından orşiektomi yapılmış, bunların da histopatolojik değerlendirme sonrasında benign kitleler olduğu anlaşılmıştır (29). Testis tümörünün multifokal olabilmesi nedeniyle testis koruyucu cerrahi öncesi kitlenin lokalizasyonu ve tümörden uzak bölgedeki küçük kitleleri tespitinde USG yetersiz kalabileceğinden dolayı USG'ye ek olarak T1 ve T2 ağırlıklı Magnetik Rezonans Görüntülemenin de yapılması önerilmektedir $(30,31)$.

Leydig hücreli tümörlerle ilgili yapılan testis koruyucu cerrahi ile ilgili olarak dört büyük seri literatürde görülmekte bu çalışmalara bakıldığında takip sürelerinin ortalama 4-8 yıl olduğunu ve sadece bir olguda lokal rekürrens haricinde lokal ya da uzak rekürrens olmadığı bildirilmektedir $(13,14,32,33)$. Az sayıda Sertoli hücreli tümörlerle ilgili bildirilmiş testis koruyucu cerrahi yapılan hastaların takiplerinde rekürrens saptanmadığı bildirilmiş̧ir $(34,35,36)$.

Asemptomatik insidental, nonpalpable ve küçük testis tümörlerine ultrasonografik taramalarda karşılaşılabilmektedir. Radikal orşiektomiye alternatif testis koruyucu cerrahi ile tedavi edilen birkaç seri göstermiştir ki palpable testis tümörlerine göre yaklaşı $\% 80^{\prime}$ ini benign histolojiye sahiptir $(27,35,37,38,39,40)$. Ultrasonografi ile tespit edilen 27 testis kitlesinin $\% 52^{\prime} \operatorname{sinin}$ benign hastalık bunlarında \%80'inin nonpalpabl oldukları bildirilmiştir (37). Benzer şekilde Sheynkin ve ark. nonpalpapl tümörlerde benign tümör prevalansının $\% 75$ olduğunu, ayrıca diğer iki çalışmada da $2 \mathrm{~cm}$ altındaki nonpalpapbl kitlelerin büyük oranda benign oldukları bildirilmiştir $(41,42,43)$. Avrupa Üroloji Derneği kılavuzunda radikal orşiektomiye alternatif tedavi yöntemi olarak önerilmekte ve senkron bilateral tümör ya da metakron kontralateral tümör ya da soliter testislerde tümör volümü testis volümünün $\% 30^{\prime}$ dan $a z$, operasyon öncesi normal testosteron seviyesi olan hastalara önerilmektedir. Özellikle jinekomasti ya da hormonal bir bozukluk durumlarında nongerm hücreli tümörler düşünülmesi ve hemen orşiektomi yapmaktan kaçınılması gerektiği önerilmektedir. Histolojik olarak malignensi bulgusu olan ve özellikle yaşlı hastalarda orşiektomi, malignensi bulgusu olmayan hastalarda testis koruyucu cerrahi küçük intraparankimal kitlelerde önerilmektedir (3).

\section{Sonuç}

TSST'leri nadir görülen tümörlerdir ancak asemptomatik, insidental, nonpalpable, küçük testis kitlelerinden ve hormonal değişiklikle giden testis kitlesinin saptandığı durumlarda malignite potansiyellerinin düşük olması ve alternatif tedavi seçenekleri açııından germ hücreli testis tümörlerinden ayıııcı tanıları yapılmalıdır. Standart tedavileri inguinal orşiektomi olmasına rağmen testis koruyucu cerrahi ile ilgili artan literatür verileri iyi seçilmiş olgularda güvenli bir alternatif tedavi olabileceğini göstermektedir.

Çıkar çatışması: Yazarlar bu makale ile ilgili olarak herhangi bir çıkar çatışması bildirmemişlerdir.

\section{Kaynaklar}

1. La Vecchia C, Bosetti C, Lucchini F, et al. Cancer Mortality in Europe, 2000-2004, and an overview of trends since 1995. Ann Oncol 2010 21:1323-1360.

2. Acar C, Gurocak S, Sozen S. Current Treatment of Testicular Sex Cord-stromal Tumors: Critical Review. Urology 2009;73:1165-1171.

3. Albers P, Albrecht W, Algaba F, et al. Guidelines on Testicular Cancer European Association of Urology, 2014.

4. Eble JN, Sauter G, Epstein JI, Sesterhenn IA. WHO histological classification of testis tumours, In: Pathology\&Genetics. Tumours of the urinary system and male genital organs. Lyon: IARC Press, 2004; 218, pp. 250-262.

5. Kim I, Young RH, Scully RE. Leydig cell tumours of the testis. A clinicopathological analysis of 40 cases and review of the literature. Am J Surg Pathol 1985;9:177-192.

6. Ulbright TM, Amin MB, Young RH. Tumours of the testis, adnexia, spermatic cord and scrotum, Washington DC: Armed Forces Institute of Pathology (AFIP), Fascicle 25, 3rd series. 1999; pp. 41-191.

7. Cheville JC, Sebo TJ, Lager DJ, et al. Leydig cell tumour of the testis: a clinicopathologic, DNA content, and MIB-1 comparison of nonmetastasizing and metastasizing tumors. Am J Surg Pathol 1998;22:1361-1367. 
8. McCluggage WG, Shanks JH, Arthur K, et al. Cellular proliferation and nuclear ploidy assessments augment established prognostic factors in predicting malignancy in testicular Leydig cell tumours. Histopathology 1998;33:361-368.

9. Reznik $Y$, Rieu M, Kuhn JM, et al. Luteinizing hormone regulation by sex steroids in men with germinal and Leydig cell tumours. Clin Endocrinol 1993;38:487-493.

10. Haas GP, Pittaluga S, Gomella L, et al. Clinical occult Leydig cell tumour presenting with gynecomastia. J Urol 1989;142:1325-1327.

11. Ruthgers JL, Young RH, Scully RE. The testicular 'tumour' of the adrenogenital syndrome. A report of six cases and review of the literature on testicular masses in patients with adrenocortical disorders. Am J Surg Pathol 1988;12:503-513.

12. Mosharafa AA, Foster RS, Bihrle R, et al. Does retroperitoneal lymph node dissection have a curative role for patients with sex cordstromal testicular tumors? Cancer 2003;98:753-757.

13. Carmignani L, Colombo R, Gadda F. Conservative surgical therapy for Leydig cell tumor. J Urol 2007;178:507-511.

14. Giannarini G, Mogorovich A, Fabris F. Long-term follow up after elective testis sparing surgery for Leydig cell tumors: a single center experience. J Urol 2007; 178:872-876.

15. Giglio M, Medica M, De Rose AF, et al. Testicular Sertoli cell tumours and relative sub-types. Analysis of clinical and prognostic features. Urol Int 2003;70:205-210.

16. Henley JD, Young RH, Ulbright TM. Malignant Sertoli cell tumours of the testis: a study of 13 examples of a neoplasm frequently misinterpreted as seminoma. Am J Surg Pathol 2002;26:541-550.

17. Esber CM, Shabsigh A, Zynger DL. Sclerosing Sertoli cell tumor without expression of typical sex cord stromal tumor markers: Case report and literature review. Pathol Res Pract 2012; 208:121-125.

18. Young RH, Koelliker DD, Scully RE. Sertoli cell tumors of the testis, not otherwise specified: a clinicopathologic analysis of 60 cases. Am J Surg Pathol 1998;22:709-721.

19. Plata $C$, Algaba F, Andújar $M$, et al. Large cell calcifying Sertoli cell tumour of the testis. Histopathology 1995;26:255-259.

20. Washecka R, Dresner MI, Honda SA. Testicular tumors in Carney's complex. J Urol 2002;167:1299-1302.

21. Young S, Gooneratne S, Straus FH, et al. Feminizing Sertoli cell tumors in boys with Peutz-Jeghers syndrome. Am J Surg Pathol 1995; 19:50-58.

22. Kaplan GW, Cromie WJ, Kelalis PP, et al. Gonadal stromal tumors: a report of the Prepuberal Testicular Tumours Registry. J Urol 1986;136:300-302.

23. Al-Bozom IA, El-Faqih SR, Hassan SH, et al. Granulosa cell tumour of the adult type. A case report and review of the literature of a very rare testicular tumour. Arch Pathol Lab Med 2000;124:1525-1528.

24. Schultz KA, Schneider DT, Pashankar F, et al. Management of Ovarian and Testicular Sex Cord-stromal Tumors in Children and Adolescents. J Pediatr Hematol Oncol 2012;34:55-63.

25. Kabay Ş. Testis koruyucu cerrahi kimlere ve nasıl yapılmalı? Üroonkoloji Bülteni 2011;3:59-62.
26. Goktaş S, Zorba OU. Testis tümörlerinde organ koruyucu cerrahi. Üroonkoloji Bülteni 2009;3:52-58.

27. Giannarini G, Dieckmann KP, Albers $P$, et al. Organ-sparing surgery for adult testicular tumours: a systematic review of the literature. Eur Urol 2010;57:780-790.

28. Arık Al, Uygur C. Testis koruyucu cerrahi. Üroonkoloji Bülteni 2004;2:6-8.

29. Passarella M, Usta MF, Bivalacqua TJ, et al. Testicular-sparing surgery: a reasonable option in selected patients with testicular lesions. BJU International 2003;91:337-340.

30. Kabay S, Yucel M, Ozbek O, et al. Testicular Adenomatoid Tumour Treated with Local Excision on the Benignity Predicting Magnetic Resonance Imaging Findings Urologia Polska 2008;61:57-59.

31. Chandak P, Shah A, Taghizadeh A, et al. Testis-sparing surgery for benign and malignant testicular tumours. Int J Clin Pract 2003;57:912-913.

32. Droupy S, Mawlawi H, Izard V, et al. Tumourectomy for the treatment of Leydig cell tumours of the testis (abstract 262). Eur Urol Suppl 2006;5:88.

33. Suardi N, Strada E, Colombo R, et al. Leydig cell tumour of the testis: presentation, therapy, long-term follow-up and the role of organsparing surgery in a single-institution experience. BJU Int 2009;103:197-200.

34. Steiner H, Höltl L, Maneschg C, et al. Frozen section analysis-guided organ-sparing approach in testicular tumors: technique, feasibility, and long-term results. Urology 2003;62: 508-513.

35. Hallak J, Cocuzza M, Sarkis AS, et al. Organ-sparing microsurgical resection of incidental testicular tumors plus microdissection for sperm extraction and cryopreservation in azoospermic patients: surgical aspects and technical refinements. Urology 2009;73:887-892.

36. Nagata M, Kurimoto $S$, Takeuchi T, et al. Tiny nodule in the testicle: case report of a Sertoli cell tumor. Int J Urol 2004;11:61-62.

37. Carmignani L, Gadda F, Gazzano G, et al. High incidence of benign testicular neoplasm diagnosed by ultrasound. J Urol 2003;170:1783-1786.

38. Gentile G, Brunocilla E, Franceschelli A, et al. Can Testis-Sparing Surgery for Small Testicular Masses Be Considered a Valid Alternative to Radical Orchiectomy? A Prospective Single-Center Study. Clin Genitourin Cancer 2013;11:522-526.

39. Eifler Jr JB, King P, Schlegel PN. Incidental testicular lesions found during infertility evaluation are usually benign and may be managed conservatively. J Urol 2008;180:261-265.

40. Powell TM, Tarter TH. Management of nonpalpable incidental testicular masses. J Urol 2006;176:96-99.

41. Sheynkin YR, Sukkarieh T, Lipke $M$, et al. Management of nonpalpable testicular tumors. Urology 2004;63:1163-1167.

42. Connolly SS, D'Arcy FT, Bredin HC, et al. Value of frozen section analysis with suspected testicular malignancy. Urology 2006;67:162-165.

43. Carmignani L, Morabito A, Gadda F, et al. Prognostic parameters in adult impalpable ultrasonographic lesions of the testicle. J Urol 2005;174:1035-1038. 